\title{
Family Planning Methods and Practices Adopted by Married Women in Anambra
}

\author{
Alagbu C. E. ${ }^{1}$, Iloghalu, A. N. ${ }^{2}$, Nnaemezie, N. $\mathrm{O}^{3}$ \\ ${ }^{1,2,3}$ Department of Human Kinetics and Health Education, Nnamdi Azikiwe University, Awka Anambra State, \\ Nigeria.
}

Corresponding Author: Nnaemezie, N. O

\begin{abstract}
Introduction: Family planning is a world-wide issue in reproductive health which tends to affect individuals of every tribe or race, irrespective of age, religion or educational level. This study investigated the family planning methods and practices adopted by married women in Anambra State. Methods: Three research questions were formulated to guide the study and two null hypotheses tested at 0.05 level of significance. The design for the study was descriptive survey. The study has a population of 133, 736 married women in Onitsha, Nnewi and Awka who were registered under the population commission of Anambra State as at August, 2019. A sample of 420 married women was involved in the study. The instrument titled "Questionnaire Family planning methods and practices adopted by married women in Anambra State was used for collection of data. The data collected was analyzed using Frequency and Percentage and Chi Square.

Results: The findings indicated that greater percentage of married women in Anambra State is aware of family planning but practicing it was the major problem. There were no significant difference in the family planning methods adopted by married women in Anambra State based on their ages and parity level.

Conclusion: Based on the findings and their implications, it was recommended among others, that there is need for there is need to create more awareness or sensitization on other methods of family planning which the women might not know.
\end{abstract}

Keywords: Family planning, reproductive health, married women, Anambra

\section{INTRODUCTION}

Procreation is one of the blessings of God for mankind yet it is being perceived as one of the major problems that are facing man economically, socially, physically and emotionally. This may be because of the difficulties encountered in controlling and avoiding unwanted pregnancies that result to unwanted babies. These difficulties tend to have led man to search for ways and means of preventing unwanted pregnancies without necessarily adopting abortion processes. Herbet, Schwandt and Galadanci (2014) defined family planning as any conscious effort to limit or space the number of children one desire to have included the search of contraceptive methods as well as family planning services.

Furthermore, Abdulkarim, Orobatan, Abagunde, Al-Rashid and Kabo (2009) emphasized the importance of family planning and the need to have children by choice and not by chance. Hence, Falaye, Taiwo, Omisite and Olakunle (2016) saw family planning as a proven approach for increasing contraceptive use with a view to reduce fertility rates globally. This is a crucial aspect of married life that allows individuals and couples to have a choice of their desired number of children and the spacing and timing of their births thereby promoting quality of life of mothers, 
children, families and individuals in any community.

Oyindamola and Akinso (2013) opined that one of the reasons for difference between positive attitude and failure to use contraceptive is that people are not very familiar with the different contraceptive methods. People could know of their existence, but may not know how to use them. It is alleged that many persons who use (or have used) contraceptive tend to worried by rumors about their side effects, while some are said to believe that family planning encourages child limiting rather than child spacing, fear of partners to become promiscuous and fear of immediate return of fertility after family planning use, perhaps due to lack of adequate information and education.

Family planning has so many benefit both to the mother, children, father and the family, which ranges from enabling the mother regain her health after delivery, children being able to get all the attention, security, love and care they deserve and for the fathers enabling them to give their children required basic needs of life (food, shelter, education and better future). The mothers will benefit from family planning by enjoying a healthier motherhood and produce healthier children. With the effort made by government and non-governmental organization to curb the negative effect of unplanned child bearing, married women still find it difficult to choose appropriate family planning method which would likely lead to low practice of those family planning methods which ought to have helped in reducing high maternal and child death and poverty, both in the family and nation at large. Despite wide spread availability of contraceptives, almost half of pregnancies are still unintended and these has lead to the legalization of abortion in some countries of the world including the developed ones.

Furthermore, Family planning helps to reduce over population which is currently being experienced in Nigeria today. The state of Nigeria population today is a matter of great concern to the general public. This concern arises from the estimated population increase figure of 140 million people at a rate of approximately 2.9 per cent per year (NPC, 2006) making her one of the countries with the fastest growing population in the world. NPC/FMOH (2004) reported that Nigeria adds about 3.5 million people to its population annually. On $17^{\text {th }}$, June 2019, European Union (EU) reported that the current population of Nigeria is 200 , 952,695 which is considered high. According to them Nigeria has $2.6 \%$ of the World population and the highest populated country in Africa. Today, family planning has been advocated as a control mechanism to regulate and control this rapid population growth, yet Nigeria has only $16 \%$ in family planning usage according to Health report stated on $17^{\text {th }}$ of April, 2019 on Network News.

It is this worrisome situation that motivated or prompted the researcher to carry out this study which intends to determine the family planning methods and practices adopted by married women in Anambra state.

\section{Purposes of the study}

The main purpose of the study is to determine the family planning methods and practices of married women in Anambra State Nigeria. The specific purposes of the study are:

1. To determine the family planning method adopted by married women in Anambra state.

2. To determine the family planning practices adopted by married women in Anambra state based on their ages.

3. To determine the family planning practices adopted by married women in Anambra state based on their parity level.

\section{Significance of the study}

The findings of this study would be of immense benefit to the married women, health educators, future researchers, 
government, family planning programme expert and administrators.

\section{Scope of the study}

The study was delimited to family planning methods and practices of married women in Anambra state. It was also delimited to independent variables of age, religion, parity and level of education. It would also cover married women in Awka, Onitsha and Nnewi metropolitan cities of Anambra state.

\section{Research Questions}

The following research questions were used for study:

1. What are the family planning methods adopted by married women in Anambra state?

2. What are the family planning practices adopted by married women in Anambra state based on their ages?

3. What are the family planning practices adopted by married women in Anambra state based on their parity level?

\section{Hypothesis}

The following null hypothesis was tested at 0.05 level of significance:

1. There will be no significant difference in the family planning practices adopted by married women in Anambra state based on their ages.

2. There will be no significant difference in the family planning practices adopted by married women in Anambra state based on their parity level.

\section{METHOD}

\section{Research Design}

The design that was used for the study was descriptive survey research design. According to Margaret (2019) it is a design which involves the collection of data attained by a sting individuals questions either in person, on paper, by phone or online.

\section{Areas of the study}

This study was carried out in Anambra State, in three urban towns in the state. The three urban towns were Onitsha, Nnewi and Awka which were considered as Metropolitan Cities of Anambra State.

\section{Population of the study}

The population for the study comprised of 133, 736 married women in Onitsha, Nnewi and Awka who were registered under the population commission of Anambra state as at (August 2019).

\section{Sample and Sampling technique}

The sample was 420 respondents gotten from the three selected urban towns used for the study, this include Onitsha 196, Awka 119 and Nnewi 105 which made up of 420 respondents. Stratified random sampling technique was used to get the 420 respondents since the towns do not have the same population.

\section{Instrument for Data Collection}

Data for this study was collected using a structured questionnaire developed by the researcher and titled "Family Planning Method and Practices Questionnaire (FPMAPQ)".

\section{Method of Data Analysis}

Descriptive statistics (frequency and percentage) were used to answer the research questions while Chi-Square was used to test hypotheses at 0.05 level of significance. In testing the null hypotheses, when $\mathrm{p}$-value is less than or equal to $0.05(\mathrm{P}$ $<0.05$ ), the null hypothesis will be rejected otherwise, the null hypothesis will be accepted.

\section{PRESENTATION AND ANALYSIS OF DATA}

This chapter presents the analysis of data collected and the results. The analyses of the research questions and hypotheses are presented item by item using tables. A summary of findings of the study is also presented. 
Research Question 1: What are the family women in Anambra State? planning methods adopted by married

Table 1: Percentage Scores of Family Planning Methods Adopted by Married Women in Anambra State

\begin{tabular}{|c|c|c|c|}
\hline $\mathbf{S} / \mathbf{N}$ & Family Planning Methods & Yes $\quad(\%)$ & No $(\%)$ \\
\hline & Modern Family Planning Method & & \\
\hline 1 & Combined oral contraceptives & $113(26.9)$ & $307(73.1)$ \\
\hline 2 & Progestogen (pills) & 81 (19.3) & $339(80.7)$ \\
\hline 3 & Implants & $357(\mathbf{8 5 . 0})$ & $63(15.0)$ \\
\hline 4 & Progestogen (injectables) & 91 (21.7) & 329 (98.3) \\
\hline 5 & $\begin{array}{l}\text { Monthly injectables or combined injectable } \\
\text { contraceptives (CIC) }\end{array}$ & $84(20.0)$ & $336(\mathbf{8 0 . 0 )}$ \\
\hline 6 & $\begin{array}{l}\text { Combined contraceptive patch and combined } \\
\text { contraceptive vaginal ring (CVR) }\end{array}$ & $59(\mathbf{1 4 . 0 )}$ & $361(\mathbf{8 6 . 0})$ \\
\hline 7 & Intrauterine device (IUD) containing copper & 377 (89.8) & $43(10.2)$ \\
\hline 8 & Intrauterine device (IUD) levonorgestrel & $53(12.6)$ & $367(87.4)$ \\
\hline 9 & Female condoms & $27(6.4)$ & 393 (93.6) \\
\hline 10 & Female sterilization (tubal ligation) & 35 (8.3) & $385(91.7)$ \\
\hline 11 & Lactational amenorrhea method (LAM) & $194(46.2)$ & $226(53.8)$ \\
\hline 12 & Emergency contraception pills & $387(92.1)$ & 33 (7.9) \\
\hline 13 & Billings Methods & 79 (18.8) & 341 (81.2) \\
\hline & Traditional Family Planning Method & & \\
\hline 14 & Calendar method or rhythm method & 368 (87.6) & $52(12.4)$ \\
\hline 15 & Withdrawal (coitus interruptus) method & $292(69.5)$ & $128(30.5)$ \\
\hline
\end{tabular}

The data in Table 1 showed that $(89.8 \%)$ practice family planning of the married women in Anambra State adopt intrauterine device (IUD) containing copper, $(87.6 \%)$ adopt calendar method or rhythm method, (92.1\%) adopt emergency contraception pills, (85\%) adopt implants.
Research Question 2: What are the family planning practices adopted by married women in Anambra State based on their ages?

Table 2: Percentage Scores of Family Planning Practices Adopted by Married Women in Anambra State Based on Their Age

\begin{tabular}{|c|c|c|c|c|c|c|c|}
\hline \multirow[t]{2}{*}{$\mathrm{S} / \mathbf{N}$} & \multirow{2}{*}{$\begin{array}{l}\text { Family Planning } \\
\text { Practices }\end{array}$} & \multicolumn{2}{|c|}{$20-29$ Years } & \multicolumn{2}{|c|}{$30-39$ Years } & \multicolumn{2}{|c|}{40 \& Above } \\
\hline & & Yes (\%) & No $(\%)$ & Yes (\%) & No $(\%)$ & Yes $(\%)$ & No $(\%)$ \\
\hline 16 & $\begin{array}{l}\text { Have you ever used } \\
\text { any family method? }\end{array}$ & 34 (26.4) & 95 (73.6) & $157(77.3)$ & $46(22.7)$ & $71(80.7)$ & $17(\mathbf{1 9 . 3 )}$ \\
\hline 17 & $\begin{array}{l}\text { Are you currently } \\
\text { using any family }\end{array}$ & & & & & & \\
\hline $18 \mathrm{a}$ & $\begin{array}{l}\text { planning method? } \\
\text { Family Planning }\end{array}$ & $23(\mathbf{1 7 . 8 )}$ & $106(82.2)$ & 146 (71.9) & $57(28.1)$ & 65 (73.9) & $23(26.1)$ \\
\hline $18 \mathrm{~b}$ & $\begin{array}{l}\text { Method in current use } \\
\text { (Modern Method) } \\
\text { Family Planning }\end{array}$ & $101(\mathbf{7 8 . 3 )}$ & $28(21.7)$ & 189 (93.1) & $14(6.9)$ & $68(77.3)$ & $20(22.7)$ \\
\hline & $\begin{array}{l}\text { Method in current use } \\
\text { (Traditional Method) }\end{array}$ & 39 (30.2) & $90(69.8)$ & $142(70.0)$ & $61(\mathbf{3 0 . 0})$ & $17(\mathbf{1 9 . 3 )}$ & $71(\mathbf{8 0 . 7 )}$ \\
\hline $19 \mathrm{a}$ & $\begin{array}{l}\text { Length of use of } \\
\text { family planning } \\
\text { method (less than }\end{array}$ & & & & & & \\
\hline & one year) & $2(1.6)$ & 127 (98.4) & 37 (18.2) & $166(\mathbf{8 1 . 8})$ & 12 (13.6) & $76(86.4)$ \\
\hline b & One to five years & $16(12.4)$ & 113 (87.6) & $164(\mathbf{8 0 . 8 )}$ & 39 (19.2) & $61(69.3)$ & $27(30.7)$ \\
\hline c & Six to ten years & $20(15.5)$ & 109 (84.5) & $4(2.0)$ & 199 (98.0) & $86(97.7)$ & $2(2.3)$ \\
\hline d & More than ten years & $4(3.1)$ & 125 (96.9) & $22(\mathbf{1 0 . 8})$ & 181 (89.2) & 78 (88.6) & $10(\mathbf{1 1 . 4 )}$ \\
\hline $20 \mathrm{a}$ & $\begin{array}{l}\text { Who makes decision } \\
\text { regarding family }\end{array}$ & & & & & & \\
\hline & planning (Wife) & 121 (93.8) & $8(6.2)$ & $172(84.7)$ & 31 (15.3) & 74 (84.1) & $14(\mathbf{1 5 . 9 )}$ \\
\hline $\mathrm{b}$ & Husband & 2 (1.6) & 127 (98.4) & $27(13.3)$ & $176(86.7)$ & 15 (17.0) & $73(\mathbf{8 3 . 0})$ \\
\hline c & Both of us & 59 (45.7) & 70 (54.3) & $65(32.0)$ & $138(68.0)$ & $27(30.7)$ & $61(69.3)$ \\
\hline d & Others & $8(6.2)$ & 121 (93.8) & 27 (13.3) & $176(86.7)$ & $15(17.0)$ & $73(\mathbf{8 3 . 0})$ \\
\hline $21 \mathrm{a}$ & $\begin{array}{l}\text { Reason for choice of } \\
\text { family planning } \\
\text { method (It is }\end{array}$ & & & & & & \\
\hline & affordable) & 15 (11.6) & 114 (88.4) & $40(19.7)$ & $163(\mathbf{8 0 . 3 )}$ & $21(23.9)$ & $67(76.1)$ \\
\hline b & Easily accessible & $11(8.5)$ & 118 (91.5) & $12(5.9)$ & 191 (94.1) & $7(8.0)$ & 81 (92.0) \\
\hline $\mathrm{c}$ & Highly effective & 114 (88.4) & 15 (11.6) & $201(\mathbf{9 9 . 0})$ & $2(1.0)$ & 78 (88.6) & $10(11.4)$ \\
\hline
\end{tabular}


Table 2 showed that $(77 \%)$ of the married women in Anambra State between the age of 30 - 39 years have ever used family planning, $(71 \%)$ are currently using family planning method, $(26 \%)$ of the women $20-29$ years have practiced family planning. Also $(93.1 \%)$ of women between the ages of $30-39$ years practiced the modern family planning, (93\%) and $(84.7 \%)$ of the women makes decision for the practice of family planning, (88.4\%), $(99.0 \%)$ and $(88.6 \%)$ of the women $20-29$ years, $30-39$ years and 40 years respectively practice family planning because it is highly effective.

Research Question 4: What are the family planning practices adopted by married women in Anambra State based on their parity level?

Table 4: Percentage Scores of Family Planning Practices Adopted by Married Women in Anambra State Based on Their Parity Level

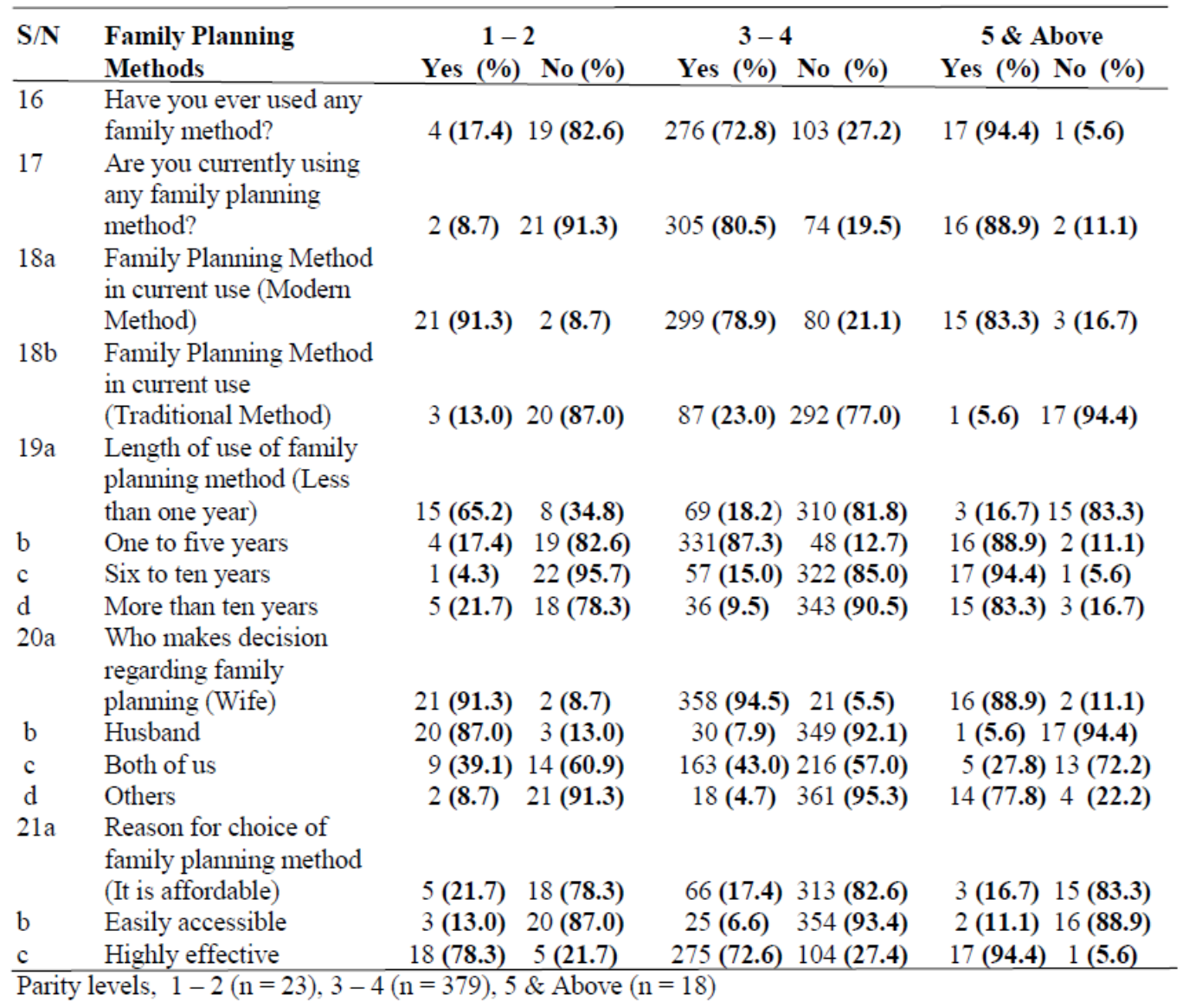

Table 4 revealed that $(72.8 \%)$ of women that have $3-4$ children and $(94.4 \%)$ of women with 5 and above number of children has ever practiced family planning, $(80.5 \%)$ of women with $3-4$ children and $(88.9 \%)$ of women with 4 and above children are currently practicing family planning, $(78.9 \%)$ of women with $3-4$ children, and $(83.3 \%)$ of women with 5 and above are practicing modern family planning, $(83.3 \%)$ of women with 5 children and above has practiced family planning for more than ten years, $(78.3 \%)$ of women with $1-2$ children, $(72.6 \%)$ of women with $3-4$ children and $(94.4 \%)$ of women with 5 children and above practice family planning because it is highly effective.

Hypothesis 2: There is no significant difference in the family planning practices adopted by married women in Anambra State based on their ages. 
Table 7: Test of Difference in the Family Planning Practices Adopted by Married Women in Anambra State Based on Their Ages

\begin{tabular}{crccccc}
\hline Age & N & df & $\boldsymbol{\alpha}$ & $\boldsymbol{x}^{2}$-Calculated & $\boldsymbol{x}^{\mathbf{2}}$-Critical & Decision \\
\hline $20-29$ & 129 & & & & & \\
$30-39$ & 203 & 2 & .05 & 2.165 & 5.991 & Accept \\
$40 \&$ Above & 88 & & & & & \\
\hline$x^{2}$-Cal $>x^{2}$-Crit & & & & &
\end{tabular}

Analysis on Table 7 shows that the value of $x^{2}$-calculated (2.165) is less than the value of $x^{2}$-critical (5.991) at .05 alpha level $(2.165>5.991)$. This implies that the null hypothesis was accepted; therefore, there is no significant difference in the family planning practices adopted by married women in Anambra State based on their ages.

Hypothesis 4: There is no significant difference in the family planning practices adopted by married women in Anambra State based on their parity level.

Table 9: Test of Difference in the Family Planning Practices Adopted by Married Women in Anambra State Based on Their Parity Level

\begin{tabular}{ccccccc}
\hline Age & N & df & A & $\boldsymbol{x}^{\mathbf{2}}$-Calculated & $\boldsymbol{x}^{\mathbf{2}}$-Critical & Decision \\
\hline $1-2$ & 23 & & & & & \\
$3-4$ & 379 & 2 & .05 & 0.086 & 5.991 & Accept \\
$5 \&$ Above & 18 & & & & &
\end{tabular}

Table 9 shows that null hypothesis is accepted given that $x^{2}$-calculated value of 0.086 is less than $x^{2}$-critical value of 5.991 . Hence, there is no significant difference in the family planning practices adopted by married women in Anambra State based on their parity level.

\section{DISCUSSION}

This chapter discussed the findings of the study, draws conclusions and makes recommendations. The chapter also discussed the implications of the study, limitations of the study as well as made suggestions for further studies.

\section{Family Planning Methods Adopted by Married Women in Anambra State}

The findings of the study showed that married women in Anambra adopt more of combined oral contraceptives, progestogen (pills), implants, intrauterine device (IUD) containing copper, Lactational amenorrhea method (LAM), emergency contraception pills all in the modern family planning method. Also for the traditional method, married women in Anambra State adopt calendar method or rhythm method and withdrawal (coitus interruptus) method. The findings also revealed that married women in Anambra State adopt more of modern family planning method than the traditional method. Also out of all the methods put together both traditional and modern family planning method, combined oral contraceptive, implants, intrauterine device (IUD) containing copper, Lactational amenorrhea method (LAM), calendar method or rhythm method and withdrawal (coitus interruptus) method are mostly adopted by married women in Anambra State. The study was in line with the study conducted by Kamruzzaman and Abdul Hakim (2015) on family planning practice among married women attending primary health care centers in Bangladesh that the women use more of condom, IUCD and implant, pills and injection. The result is not surprising because most of the modern family planning methods are highly effective and easily provided by so many health facilities. Also the null hypothesis of no significant difference in the family planning methods adopted by married women in Anambra State was accepted. 
The findings of the study revealed that women between the ages of $30-39$ years have used one of the various family planning methods followed by ages 40 years and above. Also married women between the ages $30-39$ years agreed that they are currently using one of the family planning methods also followed by women 40 years and above. Women between the years of 30 - 39 are currently using the modern family planning method followed by women between the ages of $20-29$ years. The traditional family planning methods are less in use among married women in Anambra State. Also women between the ages of 40 years and above are also making less use of the family planning methods. More women between the ages of 40 and above have used the family planning methods for less than one year; $30-39$ years have used the family planning method for one to five years, also 40 years and above have used the family planning method for up to six to ten years and more than ten years. Also women between the ages of $30-39$ years agreed that they as the wife make decision regarding family planning followed by women between the ages of $20-29$ years while less number of them agreed with their husbands deciding the family planning methods. Women between the ages of $30-$ 39 years use family planning methods because it is affordable, less number of them used it because it is accessible but more number used it because it is highly effective. This is so because women between the ages of $30-39$ years are more experienced and most time marriage usually takes place between that age brackets. Also this study is in line with the study of Eze and Okeke (2015) adoption of family planning measures among couples in New Heaven. The women between the ages of $32-44$ years adopted and practiced family planning. Also in the study of Ekponyong and Nzute (2018) supported the idea because women between the ages of $25-34$ years practice family planning. But was the against the study conducted by Rao, Mathada and Jchin (2016) on awareness and determinants of contraceptive use among nursing mothers in Bellary, Kamataka. Which reported that women between the ages of $19-29$ years practice family planning. Also the null hypothesis of no significant difference was therefore accepted.

The findings of this study showed that women that has up to $3-4$ children have practiced family planning; also good percentage of women with children 5 and above have also practiced family planning but not the same with women who has $1-2$ children. High percentage of married women who has $3-4$ children are currently using family planning method. Also women with 5 and above children have good percentage of them currently using family planning. High percentage of women who has $1-2$ children does not practice any family planning method. More percentage of women who has $3-4$ children makes use of modern family planning method. Also women who have $1-2$ children also make use of traditional family planning method. Also high percentage of women who has 3 4 children has practiced family planning in less than one year followed by women who has $1-2$ children. Good percentage of women who has $3-4$ children has practiced family planning for one to five years, six to ten years and more than ten years, followed by women who have 5 and above number of children. Majority of women who has 3-4 children agreed that they make decision regarding family planning, followed by women who has $1-2$ number of children. High percentage of women, who has $3-4$ children practice family planning because it is highly effective, followed by women who has $1-2$ children. Also good number of women with $3-4$ children practiced family planning because it is affordable. The result was so because when a mother gives birth to one, two or three children, she would start looking ways to distance on birth period from the other. Also once a woman has given birth to a particular sex of a baby for about two or three times, she starts to plan her birth in order to give a chance for the 
sex of the next baby to change. Therefore this study is in support of the study conducted by Eze and Okeke (2015) that women who has between 3 - 5 children practice family planning. But against the study conducted by Ekpenyong and Nzute (2018) those women who have $1-2$ children practice family planning but reduced in women who have between $3-4$ children. Also the null hypotheses of no significant differences based on parity of the women were accepted.

\section{CONCLUSIONS}

Based on the findings of the study, the following conclusions were made. Married women in Anambra State adopt more of modern family planning method more than the traditional family planning methods. Also women between the ages of 30 - 39 years and 40 years and above practiced family planning; also women between the ages of $30-39$ years are the women currently using one of the family planning methods. Generally the women practice more of modern family planning methods; also greater percentage of them has practiced family planning for a long period of time. High percentage of them also makes the decision regarding family planning method while a good number of them agreed that the decision of family planning method is made by both of them. Majority of the married women in Anambra State practice family planning because it is highly effective while good percentage of them practice family planning because it is affordable.

Acknowledgement: None

Conflict of Interest: None

Source of Funding: None

\section{Ethical Approval: Approved}

\section{REFERENCES}

1. Abdulkarim, M. (2009). Family planning needs and contraceptive use in female psychiatric outpatients. Turkish Journal Family Medical Primary Care, 3,32 - 5.

2. Ekpenyong, M.S., Nzute, A.I., Odejimio, S. \& Abdullahi, A.D. (2018). Factors influencing utilization of family planning services among female of reproductive age (15-45 years) in Bauchi local government area, Bauchi State. Nurse Palliat Care 3: doi: 1015761/NPC.1000180.

3. Eze, B. U. \& Okeke, A.A. (2015). Adoption of family planning measures among couples in New Heaven, Enugu State, Nigeria. Journal of Geography \& Natural Disasters. 5 (1).

4. Falaye, F. V., Taiwo, A. C., Omisile, K. O. \& Olakunle, A. R. (2014). Family planning clinics in Lagos, Nigeria: Clients, method acceptance and continuation rates. Nigerian Medical Journal, 28, 19 - 23.

5. Herbert, S. \& Galadance, T. (2014). Repositioning family planning guidelines for advocacy action - retrieved from: htt:/transition.usaid.govt/ourwork/globalheal th/pop/techareas repositioning/rfp.

6. NPC \& FMOH (2014). Population census of the Federal Republic of Nigeria. Analytical report at the national level.

7. Oyindamola, H. \& Akinso, F. (2013). Myths, misinformation, and communication about family planning and contraceptive use in Nigeria. Open Access Journal of contraception, 2, $95-105$.

8. Rao, B.S., Mathada, V.C \& JChin Diagn Res (2016). Awareness and determinants of contraceptive use among nursing mothers in Bellany, Karnataka. Epub.10(1).

How to cite this article: Alagbu C. E., Iloghalu, A. N., Nnaemezie, N. O. Family planning methods and practices adopted by married women in Anambra. Int J Health Sci Res. 2021; 11(6): 182-189. DOI: https://doi.org/10.52403/ ijhsr.20210629 